\title{
Genotypes and phenotypes of $\beta$ lactamase producing strains of Neisseria gonorrhoeae from African countries
}

\author{
EDVARD S FALK, * SOLGUN M BYGDEMAN, $†$ NILS K BIRKELAND,§ \\ BJARNE BJORVATN,§ INGEGERD KALLINGS, $\|$ ERIC G SANDSTRÖMT \\ From the Departments of *Dermatology, and $\ddagger$ Medical Microbiology, University Hospital, Tromsø, Norway; \\ the †Institution of Clinical Bacteriology, Huddinge; §Medical Department B, Haukeland University Hospital, \\ Bergen, Norway, the $\|$ Department of Bacteriology, National Bacteriological Laboratory, Stockholm; and the \\ TDepartment of Dermatovenereology, Karolinska Institute, Södersjukhuset, Stockholm, Sweden
}

SUMMARY The phenotypes and genotypes of $26 \beta$ lactamase (penicillinase) producing strains of Neisseria gonorrhoeae (PPNG) from African countries were investigated. Using the restriction enzyme technique nine different restriction enzyme patterns were found, two of them in 15 strains. Of the 26 strains, 16 belonged to serogroup WI (containing protein type IA) and 10 to serogroup WII/III (containing protein IB). Among the IA strains four different serovars were represented, whereas six serovars were found among the IB strains. Five different auxotypes were identified, of which proline requiring (found in 12 strains) and prototrophic (found in 10 strains) dominated. Twelve strains harboured a 4.4 megadalton as well as a 24.5 megadalton plasmid. A 3.2 megadalton plasmid was found in 14 strains, one of which also harboured a 24.5 megadalton plasmid. The 2.8 megadalton cryptic plasmid was present in all 26 strains. The MICs of doxycycline ranged from 0.25 to $2.0 \mathrm{mg} / \mathrm{l}$; the MIC $50 \%$ for WI strains was $0.25 \mathrm{mg} / 1$ and for WII/WIII strains $1.0 \mathrm{mg} / 1$. A total of $10 \mathrm{different}$ combinations of restriction enzyme pattern, serovar, auxotype, and plasmid were seen in the 16 WI strains compared with eight such combinations in the 10 WII/WIII strains.

As expected, the restriction enzyme technique and serological classification gave better differentiation than plasmid profiles and susceptibility to doxycycline. More relevantly, however, these techniques also compared favourably with auxotyping. When the different systems were combined, the sensitivity was greatly increased.

The incidence of infections caused by $\beta$ lactamase producing strains of Neisseria gonorrhoeae (PPNG) has dramatically increased since PPNG strains were first described in 1976. ${ }^{12}$ Although such infections now are reported from countries throughout the world (Osoba AO, unpublished observation), ${ }^{3-7}$ PPNG strains were for several years linked mainly with either South East Asia or Africa. Characteristic biological differences were found initially between representative strains from these two geographical areas. Thus strains originating from Africa mostly required arginine $\left(\mathrm{Arg}^{-}\right)$and were relatively resistant to tetracycline, whereas PPNG strains from South East Asia required

Address for reprints: Dr Edvard S Falk, Department of Dermatology, University Hospital, N-9012 Tromsø, Norway

Accepted for publication 27 October 1987 proline ( $\mathrm{Pro}^{-}$) or were prototrophic (Proto) and highly resistant to tetracyline. ${ }^{4}$ Furthermore, the African type PPNG strains carried a 3.2 megadalton $\beta$ lactamase encoding plasmid, whereas the corresponding plasmid of the Asian type PPNG strains was estimated at 4.4 megadaltons. ${ }^{48}$ The Asian type strains often also harboured a 24.5 megadalton transfer plasmid (Asia ${ }^{+}$ strains).

Subsequently, other auxotypes than $\mathrm{Arg}^{-}$have been found in PPNG strains from Africa,' and similarly the PPNG strains from Asia clearly belong to several different auxotypes, although Pro $^{-}$and Proto strains are the most prevalent. ${ }^{610} \mathrm{New}$ plasmid combinations have also been found in PPNG strains from various parts of the world. The 24.5 megadalton transfer plasmid has been found in strains carrying the 3.2 megadalton $\beta$ lactamase encoding plasmid (Afr ${ }^{+}$ 
strains), ${ }^{11-13}$ and the 4.4 megadalton plasmid has been shown in PPNG strains from Nigeria. ${ }^{14}$ These new combinations of plasmid and auxotype eliminate the distinction between the Asian and African types of PPNG strains and illustrate the great heterogeneity of PPNG strains. This heterogeneity is further underlined by modern methods of serological classification. $^{615-17}$

So far, antibiotic susceptibility testing, auxotyping, plasmid analysis, and serological classification have been the most powerful tools for differentiating between PPNG strains. In addition the so-called genomic fingerprinting based on restriction endonuclease digestion of the gonococcal DNA has proved to be useful for characterising individual gonococcal strains. ${ }^{1819}$

The present study was undertaken to compare the value of different markers as epidemiological tools. Thus, the restriction enzyme patterns of PPNG strains from different African countries correlated with the corresponding serovars as assessed by monoclonal antibodies ${ }^{1620}$ and with the auxotypes of these strains. Plasmid content and susceptibility to doxycycline were used as additional biological markers. The usefulness of combining the different markers and the occurrence of any correlations between them was also investigated.

\section{Patients, material, and methods}

\section{GONOCOCCAL STRAINS}

We studied 26 PPNG strains isolated from patients in Sweden who had acquired their infection in various African countries during 1982 and 1983. Two strains had been imported from the Canary Islands, five from The Gambia, one from Uganda, two each from Ethiopia, Kenya, and Sudan, seven from Nigeria, and one from Senegal. No specific geographical origin was identified for the remaining four African strains. No epidemiological links between any of the patients was known.

\section{RESTRICTION ENDONUCLEASE FINGER PRINTING}

The restriction enzyme technique was performed as described previously. ${ }^{18}{ }^{19}$ In short, the gonococci were harvested and lysed by adding edetic acid (EDTA), lysozyme, RNase, pronase, and Triton X-100. DNA was extracted repeatedly with chloroform and phenol, dialysed against a DNA buffer, and digested by the restriction endonuclease, Hind III. The resulting DNA fragments were separated electrophoretically. DNA from the Escherichia coli phage, P4, ${ }^{21}$ digested by Hind III was used as a fragment size marker. The gels were stained with ethidium bromide, washed, and finally photographed in ultraviolet light. The different band patterns (fingerprints) were compared visually and designated I to IX. Difference in this context was defined as the addition or subtraction of one or more well defined bands, when comparing two patterns.

\section{SEROLOGICAL CLASSIFICATION}

Serological classification into serogroups (WI or WII/ III) and serovars was performed by coagglutination as described previously ${ }^{31920}$ using the GS set of monoclonal antibodies provided by Milton Tam, Genetic Systems Corporation, Seattle, Washington, USA. The staphylococci containing protein A that were used as carriers for the coagglutination reagents were provided by Lars Rudin, Pharmacia Diagnostics AB.

The PPNG strains were distributed into serovars according to their reactions with the different monoclonal antibody reagents. The capital letters A (for WI strains) and B (for WII/III) are followed by lower case letters representing positive reactions with the corresponding coagglutination reagents (table 1).

Table 1 Antigenic characterisation of 26 African PPNG strains

\begin{tabular}{|c|c|c|c|c|c|c|c|c|c|c|c|c|c|c|c|}
\hline \multicolumn{7}{|c|}{ Protein IA specific monoclonal antibodies } & \multicolumn{7}{|c|}{ Protein IB specific monoclonal antibodies } & & \\
\hline $6 G 9$ & $4 G 5$ & $2 F 12$ & $6 D 9$ & $5 C 2$ & $5 G 9$ & $5 D I$ & $3 C 8$ & $2 D 6$ & $2 \mathrm{H7}$ & $2 G 2$ & $2 D 4$ & $3 B 10$ & $2 H I$ & & \\
\hline Epito & es det & & & & & & & & & & & & & & \\
\hline Af & Ae & $A d$ & $A g$ & $A k$ & $A i$ & $A h$ & $B a$ & $B c$ & $\mathrm{Be}$ & $B g$ & $B h$ & $B j$ & $B k$ & \multicolumn{2}{|c|}{ Serovar designation } \\
\hline & $\begin{array}{l}+ \\
+ \\
+ \\
+\end{array}$ & $\begin{array}{l}+ \\
+ \\
+\end{array}$ & + & + & $\begin{array}{l}+ \\
+\end{array}$ & $\begin{array}{l}+ \\
+\end{array}$ & $\begin{array}{l}+ \\
+\end{array}$ & $\begin{array}{l}+ \\
+ \\
+ \\
+\end{array}$ & $\begin{array}{l}+ \\
+\end{array}$ & $\begin{array}{l}+ \\
+ \\
+ \\
+\end{array}$ & + & + & $\begin{array}{l}+ \\
+ \\
+ \\
+ \\
+ \\
+\end{array}$ & $\begin{array}{l}\text { Ae } \\
\text { Aed } \\
\text { Aedgkih } \\
\text { Aedih } \\
\text { Bak } \\
\text { Back } \\
\text { Bcegk } \\
\text { Bcgk } \\
\text { Bcgjk } \\
\text { Beghk }\end{array}$ & $\begin{array}{l}(\mathrm{IA}-4,15)^{*} \\
(\mathrm{IA}-8,14) \\
(\mathrm{IA}-1,2) \\
(\mathrm{IA}-6) \\
(\text { IB-3, 6) } \\
(\mathrm{IB}-1,2) \\
(\mathrm{IB}-5,7) \\
(\mathrm{IB}-5,7) \\
(\mathrm{IB}-5,7) \\
(\mathrm{IB}-4,11)\end{array}$ \\
\hline
\end{tabular}

*Nomenclature equivalent according to Knapp et al..$^{20}$ 


\section{AUXOTYPING}

Auxotyping was performed as described by Catlin whereby the isolates were differentiated according to their requirements for proline ( $\left.\mathrm{Pro}^{-}\right)$, arginine $\left(\mathrm{Arg}^{-}\right)$, methionine ( $\left.\mathrm{Met}^{-}\right)$, hypoxanthine $\left(\mathrm{Hyx}^{-}\right)$, and uracil $\left(\mathrm{Ura}^{-}\right),{ }^{22}$ or combinations of these requirements. ${ }^{6}$ Strains with no special requirements regarding these substances are called prototrophic (Proto).

PLASMID ANALYSIS

Plasmids were identified by a method described by Eckhardt. ${ }^{23}$ South East Asian PPNG strains with plasmids of known molecular weight were included as fragment size markers.

\section{TESTING SUSCEPTIBILITY TO ANTIBIOTICS}

The susceptibility of strains to doxycycline was measured by an agar dilution test ${ }^{24}$ using gonococcus agar base (Oxoid, UK) containing $16.0-0.03 \mathrm{mg} / \mathrm{l}$ doxycycline (Pfizer, New York, USA) in twofold dilutions. From an overnight subculture $10^{7}$ colony forming units (cfu) were transferred to the agar surface by a multipoint inoculator (Mast Laboratories, England). The minimum inhibitory concentration (MIC) was defined as the lowest concentration that completely inhibited bacterial growth. The MIC 50\% was defined as the MIC of the least sensitive out of the most sensitive half of the strains.

\section{Results}

The chromosomal restriction enzyme analyses provided band patterns consisting of 40 to 45 individual lines. Among the 26 PPNG strains tested, nine different restriction enzyme patterns (tentatively labelled RE I to IX) were identified (fig 1). The most prevalent were RE I (found in nine strains) and RE VI (found in six strains). Careful examination of the band

\section{Strains of Neisseria gonorrhoeae}

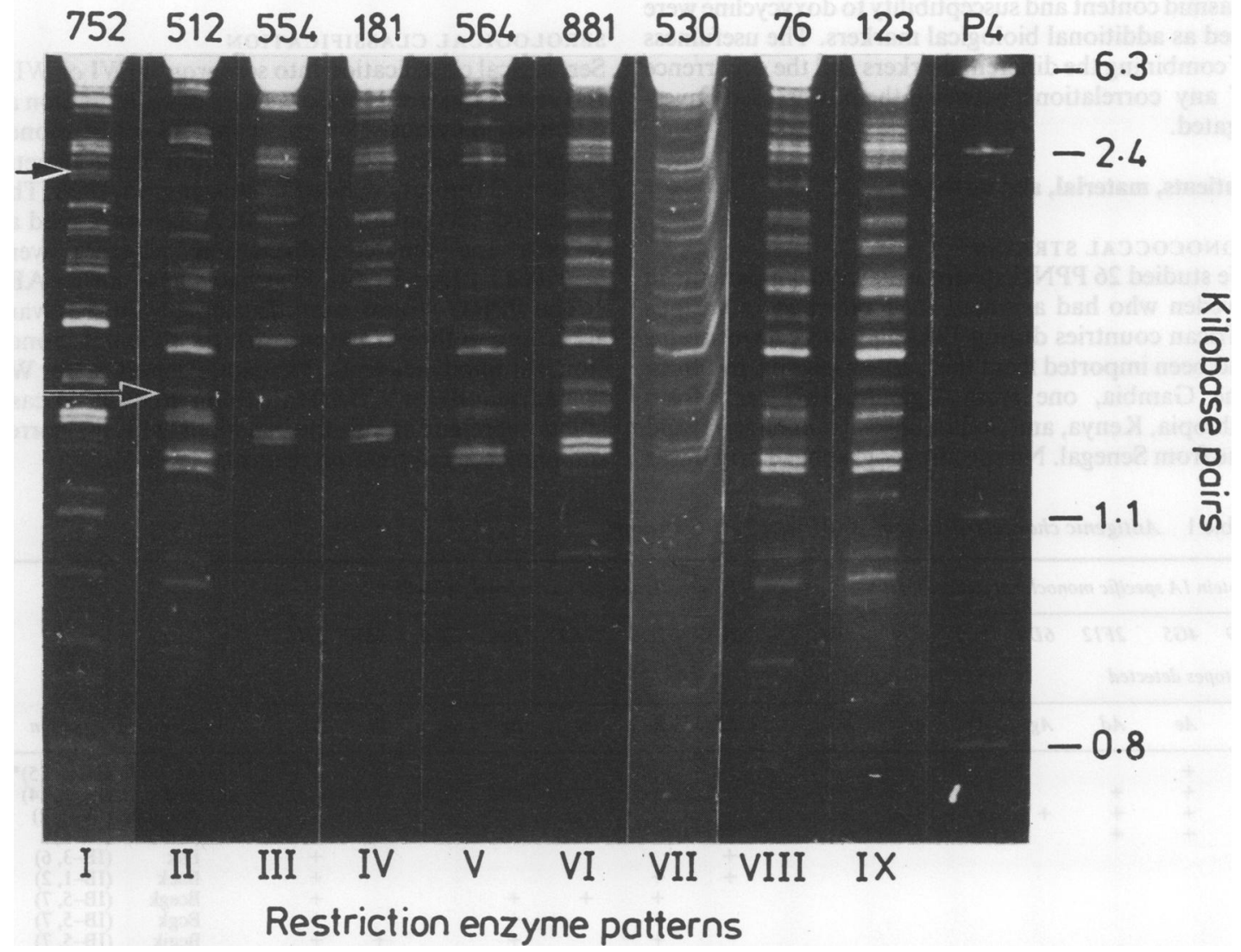

Fig 1 DNA fingerprints of nine representative $\beta$ lactamase (penicillinase) producing Neisseria gonorrhoeae (PPNG) strains. (Phage P4 used as fragment size marker. All DNA digestions by Hind III.) 
Table' 2 Distribution of 26 African PPNG strains regarding geographical origin, DNA restriction enzyme patterns, protein I serogroup and serovar patterns, plasmid patterns, auxotype, and minimum inhibitory concentrations (MIC) of doxycycline

\begin{tabular}{|c|c|c|c|c|c|c|c|c|}
\hline $\begin{array}{l}\text { Strain } \\
\text { designation }\end{array}$ & $\begin{array}{l}\text { Restriction } \\
\text { enzyme } \\
\text { pattern }\end{array}$ & Auxotype & $\begin{array}{l}\text { Serogroup } \\
\text { serovar* }\end{array}$ & $p$ and & $\begin{array}{l}\text { Plasmid } \\
\text { size } \\
\text { (megadaltons) }\end{array}$ & $\begin{array}{l}\text { Presence of } \\
\text { transfer } \\
\text { plasmid }(24 \cdot 5 \\
\text { megadaltons })\end{array}$ & $\begin{array}{l}M I C \\
(m g / l)\end{array}$ & Origin \\
\hline $\left.\begin{array}{r}752 \\
1389 \\
250 \\
1392 \\
623 \\
744 \\
1388 \\
440 \\
536\end{array}\right\}$ & I & $\begin{array}{l}\text { Proto } \\
\text { Proto } \\
\text { Proto } \\
\text { Proto } \\
\text { Proto } \\
\text { Proto } \\
\text { Proto } \\
\text { Proto } \\
\text { Proto }\end{array}$ & $\begin{array}{l}\text { Aedgkih } \\
\text { Ae } \\
\mathrm{Ae} \\
\mathrm{Ae} \\
\mathrm{Ae} \\
\mathrm{Ae} \\
\mathrm{Ae} \\
\text { Aed } \\
\text { Bcegk }\end{array}$ & $\begin{array}{l}(\text { IA-1, 2) } \\
(\text { IA-4, 15) } \\
(\text { IA-4, 15) } \\
(\text { IA-4, 15) } \\
(\text { IA-4, 15) } \\
(\text { IA-4, 15) } \\
(\text { IA-4, 15) } \\
(\text { IA-8, 14) } \\
(\text { IB-5, 7) }\end{array}$ & $\begin{array}{l}3 \cdot 2 \\
3 \cdot 2 \\
3 \cdot 2 \\
3 \cdot 2 \\
3 \cdot 2 \\
3 \cdot 2 \\
3 \cdot 2 \\
3 \cdot 2 \\
4 \cdot 4\end{array}$ & $\begin{array}{l}\text { Absent } \\
\text { Absent } \\
\text { Absent } \\
\text { Absent } \\
\text { Absent } \\
\text { Absent } \\
\text { Absent } \\
\text { Absent } \\
\text { Present }\end{array}$ & $\begin{array}{l}0.25 \\
0.25 \\
0.25 \\
0.25 \\
0.25 \\
0.25 \\
0.25 \\
1.0 \\
2.0\end{array}$ & $\begin{array}{l}\text { Canary Islands } \\
\text { Canary Islands } \\
\text { The Gambia } \\
\text { The Gambia } \\
\text { Uganda } \\
\text { Ethiopia } \\
\text { Unspecified } \\
\text { Kenya } \\
\text { Nigeria }\end{array}$ \\
\hline 512 & II & Proto & Bcegk & $(\mathrm{IB}-5,7)$ & $4 \cdot 4$ & Present & $2 \cdot 0$ & Nigeria \\
\hline $\left.\begin{array}{l}554 \\
430 \\
561\end{array}\right\}$ & III & $\begin{array}{l}\text { Pro- } \\
\text { Pro- } \\
\text { Pro- }\end{array}$ & $\begin{array}{l}\text { Aedgkih } \\
\text { Aedih } \\
\text { Aedih }\end{array}$ & $\begin{array}{l}(\mathrm{IA}-1,2) \\
(\mathrm{IA}-6) \\
(\mathrm{IA}-6)\end{array}$ & $\begin{array}{l}4 \cdot 4 \\
4 \cdot 4 \\
4 \cdot 4\end{array}$ & $\begin{array}{l}\text { Present } \\
\text { Present } \\
\text { Present }\end{array}$ & $\begin{array}{l}0.5 \\
0.5 \\
0.5\end{array}$ & $\begin{array}{l}\text { The Gambia } \\
\text { The Gambia } \\
\text { The Gambia }\end{array}$ \\
\hline $\begin{array}{l}181 \\
819\end{array}$ & IV & $\begin{array}{l}\text { Pro } \\
\text { Pro }\end{array}$ & $\begin{array}{l}\text { Aedgkih } \\
\text { Aedgkih }\end{array}$ & $\begin{array}{l}(\mathrm{IA}-1,2) \\
(\mathrm{IA}-1,2)\end{array}$ & $\begin{array}{l}3 \cdot 2 \\
3 \cdot 2\end{array}$ & $\begin{array}{l}\text { Absent } \\
\text { Present }\end{array}$ & $\begin{array}{l}1.0 \\
0.5\end{array}$ & $\begin{array}{l}\text { Nigeria } \\
\text { Nigeria }\end{array}$ \\
\hline 564 & V & Pro $^{-}$ & Aedgkih & $(\mathrm{IA}-1,2)$ & $4 \cdot 4$ & Present & 0.25 & Unspecified \\
\hline $\left.\begin{array}{r}881 \\
528 \\
1283 \\
285 \\
286 \\
763\end{array}\right\}$ & VI & $\begin{array}{l}\text { Pro- } \\
\text { Pro- } \\
\text { Pro- } \\
\text { Pro- } \\
\text { Pro- } \\
\text { Pro- }\end{array}$ & $\begin{array}{l}\text { Aedih } \\
\text { Beghk } \\
\text { Back } \\
\text { Bak } \\
\text { Bak } \\
\text { Bcgjk }\end{array}$ & $\begin{array}{l}(\text { IA-6) } \\
(\text { IB-4, 11) } \\
(\text { IB-1, 2) } \\
(\text { IB-3, 6) } \\
(1 \mathrm{~B}-3,6) \\
(\text { IB-5, 7) }\end{array}$ & $\begin{array}{l}4 \cdot 4 \\
4 \cdot 4 \\
4 \cdot 4 \\
4 \cdot 4 \\
4 \cdot 4 \\
4 \cdot 4\end{array}$ & $\begin{array}{l}\text { Present } \\
\text { Present } \\
\text { Present } \\
\text { Present } \\
\text { Present } \\
\text { Present }\end{array}$ & $\begin{array}{l}1 \cdot 0 \\
2 \cdot 0 \\
1 \cdot 0 \\
2 \cdot 0 \\
2 \cdot 0 \\
0 \cdot 5\end{array}$ & $\begin{array}{l}\text { Sudan } \\
\text { Kenya } \\
\text { Nigeria } \\
\text { Unspecified } \\
\text { Unspecified } \\
\text { Sudan }\end{array}$ \\
\hline 530 & VII & Pro $^{-}$Met $^{-}$ & Aedih & $(\mathrm{IA}-6)$ & $3 \cdot 2$ & Absent & 0.5 & Senegal \\
\hline 76 & VIII & Arg- & Bcgjk & $($ IB-5, 7$)$ & $3 \cdot 2$ & Absent & 0.5 & Ethiopia \\
\hline $\left.\begin{array}{l}123 \\
144\end{array}\right\}$ & IX & $\begin{array}{l}\text { Pro }^{-} \text {Arg }^{-} \\
\text {Pro }^{-} \text {Arg }^{-}\end{array}$ & $\begin{array}{l}\text { Bcgk } \\
\text { Bcgk }\end{array}$ & $\begin{array}{l}(\mathrm{IB}-5,7) \\
(\mathrm{IB}-5,7)\end{array}$ & $\begin{array}{l}3 \cdot 2 \\
3 \cdot 2\end{array}$ & $\begin{array}{l}\text { Absent } \\
\text { Absent }\end{array}$ & $\begin{array}{l}1.0 \\
1.0\end{array}$ & $\begin{array}{l}\text { Nigeria } \\
\text { Nigeria }\end{array}$ \\
\hline
\end{tabular}

*Nomenclature equivalent according to Knapp et al..$^{20}$

patterns showed that the difference between restriction enzyme patterns I and II resulted from the absence or presence of a band in two locations only (arrows). Restriction enzyme patterns III to VI showed equally minor differences, but clearly differed from the patterns of all the other isolates. Thus, restriction enzyme pattern III differed from pattern V, and pattern IV from pattern VI by the omission of one band only, at the same location. Restriction enzyme patterns IV and VI differed from patterns III and V by the omission of two bands at the same location. Restriction enzyme pattern VII clearly differed from all other patterns, whereas restriction enzyme patterns VIII and IX differed from each other by only one band.

Table 2 shows that the 4.4 megadalton plasmid was found in 12 strains, all of which also carried the 24.5 megadalton conjugative plasmid $\left(\mathrm{Asia}^{+}\right.$). The remaining 14 strains contained the 3.2 megadalton plasmid. In only one strain the 24.5 megadalton plasmid coexisted with the 3.2 megadalton plasmid $\left(\mathrm{Afr}^{+}\right)$(fig 2). The cryptic 2.8 megadalton plasmid was present in all 26 strains.
Table 3 shows that five different auxotypes were identified: 12 strains were Pro $^{-}$and 10 were Proto. The four remaining strains were of the auxotypes Pro $^{-}$ $\mathrm{Arg}^{-}$(two strains), $\mathrm{Pro}^{-} \mathrm{Met}^{-}$, and $\mathrm{Arg}^{-}$(one strain each). Serogroup WI was represented by 16 isolates, six of which belonged to the serovar Ae, five to Aedgkih, four to Aedih, and one to Aed. Serogroup WII/III was represented by 10 strains belonging to six different serovars, each represented by one or two strains.

The MIC $50 \%$ values of doxycycline were 0.25 $(0.25-1.0) \mathrm{mg} / 1$ for WI strains and $1.0(0.5-2.0) \mathrm{mg} / 1$ for WII/III strains (table 4).

Six different combinations of serovars and auxotypes were identified in the 16 WI strains (table 3). Aedgkih/Pro ${ }^{-}$strains could be either $\mathrm{Afr}^{-}, \mathrm{Afr}^{+}$, or $\mathrm{Asia}^{+}$. Thus eight different combinations of serovars, auxotypes, and plasmids were found (table 4). Among the $10 \mathrm{WII} / \mathrm{III}$ strains, seven different combinations of serovar and auxotype (table 3 ) and serovar, auxotype, and plasmid (table 4) were identified.

Combining the results of the restriction enzyme 


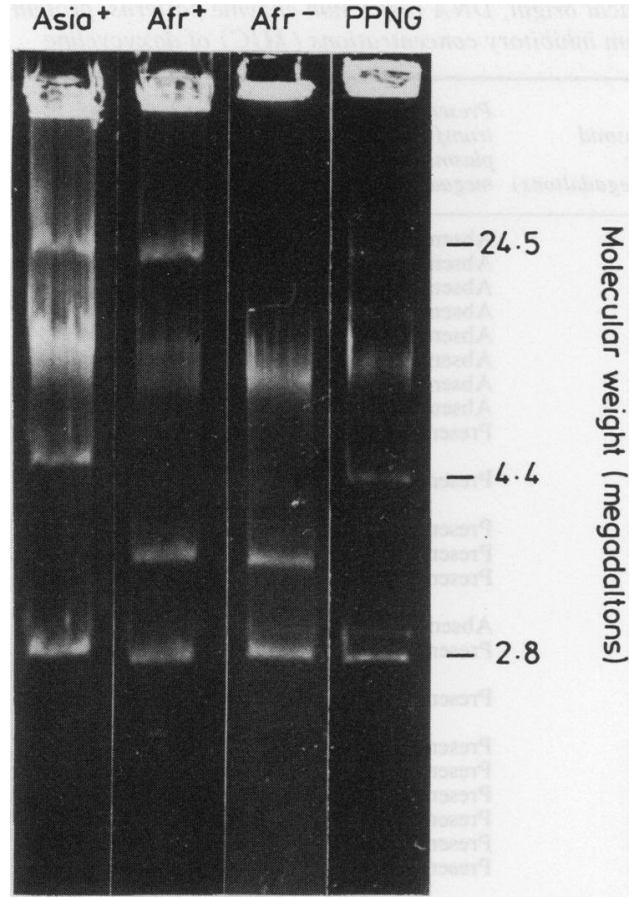

Fig 2 Plasmids carried by representative $\beta$ lactamase (penicillinase) producing strains of Neisseria gonorrhoeae (PPNG): Asia $^{+}$(containing 4.4 and 24.5 megadalton plasmids), $\mathrm{Afr}^{+}$(3.2 and 24.5 megadalton plasmids), $A f r^{-}$ ( $3 \cdot 2$ megadalton plasmid only). PPNG strain from South East Asia with plasmids of known molecular weight included as fragment size marker.

analyses with the information on auxotypes, some interesting correlations occurred (table 5): each restriction enzyme pattern was associated with only one auxotype. Thus all nine strains of restriction enzyme pattern I belonged to the Proto auxotype, whereas all six strains of restriction enzyme pattern VI were of

Table 3 Combinations of serovars and auxotypes in 26 African PPNG strains

\begin{tabular}{lllll}
\hline & \multicolumn{2}{l}{ Auxotype } & & \\
\cline { 2 - 5 } Serovar & Proto & $\mathrm{Pro}^{-}$ & $\mathrm{Pro}^{-} \mathrm{Met}^{-} \mathrm{Pro}^{-} \mathrm{Arg}^{-} \mathrm{Arg}^{-}$ \\
\hline Ae & 6 & & & \\
Aed & 1 & 4 & & \\
Aedgkih & 1 & 3 & 1 & \\
Aedih & & 2 & & \\
Bak & & 1 & & 2 \\
Back & & 1 & & \\
Bcgk & & 1 & & \\
Bcgk & 2 & 1 & & \\
Bcegk & 2 & 1 & & \\
Beghk & & &
\end{tabular}

Table 4 Minimum inhibitory concentration (MIC) of . doxycycline and restriction enzyme $(R E)$ pattern of 26 $P P N G$ strains with different combinations of serovar, auxotype, and plasmid contents

\begin{tabular}{|c|c|c|c|}
\hline $\begin{array}{l}\text { Serovar/ } \\
\text { auxotype/plasmid* }\end{array}$ & $\begin{array}{l}\text { No of } \\
\text { strains }\end{array}$ & $\begin{array}{l}\text { MIC (mg/l) of } \\
\text { doxycycline }\end{array}$ & $\begin{array}{l}R E \\
\text { pattern }\end{array}$ \\
\hline 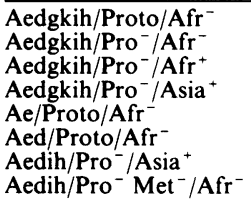 & $\begin{array}{l}1 \\
1 \\
1 \\
2 \\
6 \\
1 \\
3 \\
1\end{array}$ & $\begin{array}{l}0 \cdot 25 \\
1 \cdot 0 \\
0 \cdot 5 \\
0 \cdot 25-0.5 \\
0 \cdot 25 \\
1 \cdot 0 \\
0 \cdot 5-1 \cdot 0 \\
0 \cdot 5\end{array}$ & $\begin{array}{l}\text { I } \\
\text { IV } \\
\text { IV } \\
\text { III, V } \\
\text { I } \\
\text { I } \\
\text { III, VI } \\
\text { VII }\end{array}$ \\
\hline $\begin{array}{l}\text { Bcgk/Pro }{ }^{-} \mathrm{Arg}^{-} / \mathrm{Afr}^{-} \\
\text {Bcgjk/Arg } / \mathrm{Afr}^{-} \\
\text {Bcgjk/Pro } \\
\text { Bcegk/Asia } \\
\text { Beto/Asia } \\
\text { Beghk/Pro }^{+} / \mathrm{Asia}^{+} \\
\text {Back/Pro }^{-} / \mathrm{Asia}^{+} \\
\text {Bak/Pro }^{-} / \mathrm{Asia}^{+}\end{array}$ & $\begin{array}{l}2 \\
1 \\
1 \\
2 \\
1 \\
1 \\
2\end{array}$ & $\begin{array}{l}1 \cdot 0 \\
0 \cdot 5 \\
0 \cdot 5 \\
2 \cdot 0 \\
2 \cdot 0 \\
1 \cdot 0 \\
2 \cdot 0\end{array}$ & $\begin{array}{l}\text { IX } \\
\text { VIII } \\
\text { VI } \\
\text { I, II } \\
\text { VI } \\
\text { VI } \\
\text { VI }\end{array}$ \\
\hline
\end{tabular}

${ }^{*} \mathrm{Afr}^{+}$(3.2 and 24.5 megadalton plasmids), $\mathrm{Afr}^{-}(3.2$ megadalton plasmid), Asia $^{+}$(4.4 and 24.5 megadalton plasmids).

auxotype $\mathrm{Pro}^{-}$. On the other hand, the $12 \mathrm{Pro}^{-}$strains were distributed on four (III, IV, V, and VI), and the 10 Proto strains on two (I and II), different restriction enzyme patterns.

Some correlation was also observed between the distribution of restriction enzyme patterns and serovars (table 6). Thus restriction enzyme pattern I was found in all six strains of serovar Ae. In general, however, each restriction enzyme pattern tended to be associated with several different serovars and vice versa.

Similarly a search for covariation between auxotypes and serovars (table 3 ) did not disclose strong interrelations except, as expected, between serovar $\mathrm{Ae}$ and the Proto auxotype.

\section{Discussion}

In this study we compared different methods for differentiating between gonococcal strains. By definition, all representatives of a bacterial clone should produce identical results, regardless of test methods. On the other hand, mutational changes could affect one or more of the clonal characteristics, such as nutritional requirements, antigen reactivity, plasmid profile or restriction enzyme pattern. Our study illustrates the complex picture that emerges when several variables are used jointly for classifying closely related strains.

There was obviously certain covariation between restriction enzyme pattern and auxotype. Thus restriction enzyme patterns I and II were linked to the Proto auxotype and the restriction enzyme patterns III and IV to the $\mathrm{Pro}^{-}$auxotype. Clearly the restriction 
Table 5 Correlation between restriction enzyme patterns and auxotypes of 26 African PPNG strains

\begin{tabular}{|c|c|c|c|c|c|c|c|c|c|}
\hline \multirow[b]{2}{*}{ Auxotype } & \multicolumn{9}{|c|}{ Restriction enzyme pattern } \\
\hline & $I$ & II & $I I I$ & $I V$ & $\boldsymbol{V}$ & $V I$ & $V I I$ & $V I I I$ & $I X$ \\
\hline $\begin{array}{l}\text { Proto } \\
\text { Pro }^{-} \\
\text {Pro }^{-} \text {Met }^{-} \\
\text {Arg }^{-} \\
\text {Pro }^{-} \text {Arg }^{-}\end{array}$ & 9 & 1 & 3 & 2 & 1 & 6 & 1 & 1 & 2 \\
\hline
\end{tabular}

enzyme technique permits a higher degree of differentiation between closely related strains than auxotyping. The small differences between the restriction enzyme patterns linked with the Proto auxotype on the one hand and those associated with auxotype $\mathrm{Pro}^{-}$on the other might indicate that the same genetic variation affects both systems.

Certain plasmid profiles used to have firm geographical links. Recent observations of new plasmid combinations were, however, confirmed in this study; the traditional South East Asian PPNG type was found in an African setting. Among the 13 strains with the transfer plasmid 11 different combinations of restriction enzyme, serovar, and auxotype were seen. The 13 strains without the transfer plasmid contained seven combinations, and the clone Ae/Proto accounted for six strains. The transfer plasmid was found in only one of the 14 strains with the 3.2 megadalton plasmid, but in all 12 strains carrying the 4.4 megadalton plasmid. The 3.2 megadalton plasmid, however, was found in seven different combinations of restriction enzyme, serovar, and auxotype, whereas the $4 \cdot 4$ megadalton plasmid was found in nine. $R$ (resistance) plasmids may spread independently of the transfer plasmid, but the 24.5 megadalton plasmid may often be lost after transfer.

The strong correlation between auxotype and $\mathbf{R}$ plasmid type could lead to the conclusion that only a limited number of PPNG clones had proliferated.

Table 6 Correlations between restriction enzyme patterns and serovars of 26 African PPNG strains

\begin{tabular}{|c|c|c|c|c|c|c|c|c|c|}
\hline \multirow[b]{2}{*}{ Serovar } & \multicolumn{9}{|c|}{ Restriction enzyme pattern } \\
\hline & $I$ & II & III & $I V$ & $V$ & $V I$ & $V I I$ & $V I I I$ & $I X$ \\
\hline $\begin{array}{l}\text { Ae } \\
\text { Aed } \\
\text { Aedgkih } \\
\text { Aedih }\end{array}$ & $\begin{array}{l}6 \\
1 \\
1\end{array}$ & & $\begin{array}{l}1 \\
2\end{array}$ & 2 & 1 & 1 & 1 & & \\
\hline $\begin{array}{l}\text { Babk } \\
\text { Babck } \\
\text { Bbcgk } \\
\text { Bbcgjk } \\
\text { Bcegk } \\
\text { Beghk }\end{array}$ & 1 & 1 & & & & $\begin{array}{l}2 \\
1 \\
1 \\
1\end{array}$ & & 1 & 2 \\
\hline
\end{tabular}

Additional information provided by identifying serovars, however, shows that the plasmids are present in many different gonococcal strains. Frequent coinfection with multiple gonococcal strains could account for this great variability. Furthermore, the high number of $\mathrm{Ae} /$ Proto strains indicates that this combination of serovar and auxotype has a propensity for survival and spread, as has been observed in several other studies. ${ }^{25-27}$ In fact, several PPNG outbreaks with Ae/ Proto strains have been reported, and Ae is one of the three most common WI serovars world wide. ${ }^{25}$

The African PPNG strains in this study were more sensitive to doxycycline than previously described strains originating from the Far East. ${ }^{19}$ The correlations between susceptibility to doxycycline and serogroups, however, were similar in the two studiesstrains belonging to serogroup WI were more sensitive (MIC 50\% 0.25 mg/l) than those belonging to the WII/ WIII serogroup (MIC $50 \% 1.0 \mathrm{mg} / \mathrm{l}$ ). Similar observations have been reported by Bygdeman. ${ }^{28}$

The combination of different laboratory techniques clearly enhances the ability to discriminate between closely related strains. In this particular material auxotyping was of limited value. In other studies auxotyping has proved valuable as a complement to serovar identification, although the method requires considerable resources. The restriction enzyme technique is labour intensive and the reagents rather expensive. Depending on the choice of enzymes, however, the technique has a potential for great differentiation. Its value for exact classification may be further improved in combination with Southern blotting with defined probes. Serovar classification is simple and offers sufficient differentiation for most purposes, but still suffers from lack of standardisation of reagents, which in turn impairs comparison of results between scientists working in this discipline.

\section{References}

1 Phillips I. $\beta$-lactamase-producing penicillin-resistant gonococcus. Lancet 1976;ii:656-7.

2 Ashford WA, Golash RG, Hemming VG. Penicillinaseproducing Neisseria gonorrhoeae. Lancet 1976;ii:657-8.

3 Jephcott AE, Dickgiesser N, McClean AN. Penicillinaseproducing gonococci in Britain. Lancet 1981;ii:247-8.

4 Perine PL, Thornsberry C, Schalla W, et al. Evidence for two distinct types of penicillinase-producing Neisseria gonorrhoeae. Lancet 1977;ii:993-5.

5 Ødegaard $\mathrm{K}$, Solberg $\mathrm{O}$. Isolation of a penicillinase producing strain of Neisseria gonorrhoeae. Acta Pathol Microbiol Scand [B] 1976;84:458-60.

6 Bygdeman S, Kallings I, Danielsson D. Serogrouping and auxotyping for epidemiological study of beta-lactamase-producing Neisseria gonorrhoeae strains isolated in Sweden. Acta Derm Venereol (Stockh) 1981;61:329-34.

7 Thin RN, Barlow D, Eykyn S, Phillips I. Imported penicillinase producing Neisseria gonorrhoeae becomes endemic in London. 
British Journal of Venereal Diseases 1983;59:364-8.

8 Roberts M, Falkow S. Conjugal transfer of R plasmids in Neisseria gonorrhoeae. Nature 1977;266:630-1.

9 Odugbemi TO, Brown ST, Biddle J, et al. Plasmid profile, serogrouping, and auxotyping of Neisseria gonorrhoeae isolates from Africa. British Journal of Venereal Diseases 1983;59:41-3.

10 Odugbemi TO, Whittington WL, DeWitt W, et al. Epidemiological characterisation of Neisseria gonorrhoeae isolates from the Far East. British Journal of Venereal Diseases 1983;59:285-8.

11 Dillon JR, Pauzé M. Appearance in Canada of Neisseria gonorrhoeae strains with a 3.2 megadalton penicillinase-producing plasmid and a 24.5 megadalton transfer plasmid. Lancet 1981;ii:700.

12 Ansink-Schipper MD, van Embden JDA, van Klingeren B, Woudstra R. Further spread of plasmids among different auxotypes of penicillinase-producing gonococci. Lancet 1982;ii:445.

13 Johnston NA, Kolator B. Emergence in Britain of beta-lactamaseproducing gonococci with new plasmid combination. Lancet 1982;ii:445-6.

14 Anderson B, Odugbemi TO, Johnson S. Penicillinase producing Neisseria gonorrhoeae strains from Nigeria with Far Eastern type plasmid. Lancet 1982;i:676.

15 Handsfield HH, Sandström EG, Knapp JS, Sayers DE, Whittington WL, Holmes KK. Epidemiology of penicillinase-producing Neisseria gonorrhoeae infections. N Engl J Med 1982;306:950-4.

16 Bygdeman S, Danielsson D, Sandström E. Gonococcal W serogroups in Scandinavia. A study with polyclonal and monoclonal antibodies. Acta Pathol Microbiol Immunol Scand [B] 1983;91:293-305.

17 Bygdeman S, Gillenius E-C, Sandström EG. Comparison of two different sets of monoclonal antibodies for the serological classification of Neisseria gonorrhoeae. In: Schoolnik GK Brooks GF, Falkow S, et al, eds. The pathogenic neisseriae. Washington DC: American Society for Microbiology, 1985: $31-6$.

18 Falk ES, Bjorvatn B, Danielsson D, Kristiansen B-E, Melby K,
Sørensen B. Restriction endonuclease fingerprinting of chromosomal DNA of Neisseria gonorrhoeae. Acta Pathol Microbiol Immunol Scand [B] 1984;92:271-8.

19 Falk ES, Danielsson D, Bjorvatn B, et al. Phenotypic and genotypic characterization of penicillinase-producing strains of Neisseria gonorrhoeae. Acta Pathol Microbiol Immunol Scand [B] 1985;93:91-7.

20 Knapp JS, Tam MR, Nowinsky RC, Holmes KK, Sandström EG. Serological classification of Neisseria gonorrhoeae with use of monoclonal antibodies to gonococcal outer membrane protein I. J Infect Dis 1984;150:44-8.

21 Inman R, Schnös M, Simon I, Six EW, Walker D. Some morphological properties of P4 bacteriophage and P4 DNA. Virology 1971;44:67-72.

22 Catlin BW. Nutritional profiles of Neisseria gonorrhoeae, Neisseria meningitidis and Neisseria lactamica in chemically defined media and the use of growth requirements for gonococcal typing. J Infect Dis 1973;128:178-94.

23 Eckhardt T. A rapid method for the identification of plasmid deoxyribonucleic acid in bacteria. Plasmid 1978;1:584-8.

24 Ericsson HM, Sherris JC. Antibiotic sensitivity testing. Report of an international collaborative study. Acta Pathol Microbiol Scand [ B] 1971;suppl 217:1-90.

25 Bygdeman S. Polyclonal and monoclonal antibodies applied to the epidemiology of gonococcal infection. In: Young H, McMillan A, eds. Immunological diagnosis of sexually transmitted diseases. New York: Marcel Decker, 1987:117-65.

26 Ramstedt KM, Hallhagen GJ, Bygdeman SM, et al. Serologic classification and contact-tracing in the control of microepidemics of $\beta$-lactamase-producing Neisseria gonorrhoeae. Sex Transm Dis 1985;12:209-14.

27 Ansink-Schipper MC, Bygdeman SM, van Klingeren B, Sandström EG. Serovars, auxotypes, and plasmid contents of PPNG strains from outbreak in Amsterdam. Genitourin Med 1987;63:157-9.

28 Bygdeman S. Antibiotic susceptibility of Neisseria gonorrhoeae in relation to serogroups. Acta Pathol Microbiol Scand [B] 1981;89:227-37. 